Southeastern University

FireScholars

Selected Faculty Publications

2016

\title{
A Biblical Investigation of Matriarchal Structures in Ancient Semitic Life
}

Margaret English de Alminana

Southeastern University - Lakeland

Follow this and additional works at: https://firescholars.seu.edu/seu_papers

Part of the Biblical Studies Commons, and the History of Christianity Commons Copyright Statement

Southeastern University works are protected by copyright. They may be viewed or downloaded from this site for the purposes of research and scholarship. Reproduction or distribution for commercial purposes is prohibited without written permission of the author.

\section{Recommended Citation}

English de Alminana. 2016. "A Biblical Investigation of Matriarchal Structures in Ancient Semitic Life." Journal Of Pentecostal Theology 25, no. 1: 58-73.

This Article is brought to you for free and open access by FireScholars. It has been accepted for inclusion in Selected Faculty Publications by an authorized administrator of FireScholars. For more information, please contact firescholars@seu.edu. 
A Biblical Investigation of Matriarchal Structures in Ancient Semitic Life ${ }^{1}$

Margaret English de Alminana, $\mathrm{PhD}$

Southeastern University

1000 Longfellow Blvd

Lakeland, FL 33801

madealminana@seu.edu

Short abstract: This paper shall demonstrate that a gender-stratified template for the leadership of family and government believed to be modeled after ancient Semitic patriarchal structures according to a pattern found in Old Testament biblical texts is erroneous. It shall demonstrate that strong elements of matriarchalism existed alongside of patriarchalism, and that Old Testament texts offer no accurate template for gender-based governance.

Keywords: matriarch, patriarch, kinship, matrilineal, patrilineal, eponym

$1 \quad$ Introduction

Patriarchalism has been modeled to the church since the second century, and since the midtwentieth century in Pentecostalism, which was earlier distinguished by a widespread, inclusive embrace of both female and male leaders. Still, the lens or 'script' ${ }^{2}$ commonly employed through which one views the world according to a gender-stratified social order, often constructing such ordering based upon a reading of Old Testament biblical narratives, is of surprisingly recent derivation.

\footnotetext{
${ }^{1}$ This article was part of a previously presented paper at the $44^{\text {th }}$ Annual Meeting of the Society for Pentecostal Studies held at Southeastern University, Lakeland, Florida, in 2015.

2 'We are scripted by a process of nurture, formation and socialization that might go under the rubric of liturgy. Some of the liturgy is intentional work, much of it is incidental; but all of it, especially for the young and especially for the family, involves modeling the way the world "really is." The script is inhaled along with every utterance and every gesture, because the script-bestowing community is engaged in the social construction of a distinct reality,' see Walter Brueggemann, 'Counterscript: Living with the Elusive God,' Christian Century, Nov. 29, $2005,1$.
} 
'The term patriarchy,' says Carol Meyers, 'denotes the social-science concept of male dominance. Although the concept of patriarchy has been widely embraced and understood since that time, the genesis of identifying patriarchalism as a social organizing theory has not been as well known. The concept itself was formulated by nineteenth century anthropologists using classical literature, especially legal texts, in their attempts to understand the history of the family. By the early twentieth century, sociologists (notably Weber) extended the concept of patriarchy to include society-wide male domination. ${ }^{3}$ The methodology of this paper employs some of these early primary writings that framed the identification and creation of this lens or 'script,' which draws upon some elements of anthropology and sociology, in addition to reviewing secondary, more contemporary scholarship respecting this material. It also employs the biblical study of texts containing certain Old Testament social laws and tribal customs.

According to Lee Johnson, 'Every society has an organized structure that reflects what is valued by that society. Those members of the society that are deemed more valuable or that contribute more to the society are rewarded with a larger share of the good and services. The ancient Mediterranean world functioned within a rigid hierarchal structure in which the most valued members were opened designated - in the family, the city, the empire, and the cosmos. The virtues of the social stratification system were made apparent through the patronage/clientage system as the means of distribution of goods, the cultural battle for honor and the aversion to shame, and the patriarchal structure of the family. ${ }^{4}$ By way of definition, Necla Mora offers the following: 'The patriarchy concept, establishing the Male supremacy in the society, is a form of organization which defines every social, political, economic and cultural

\footnotetext{
${ }^{3}$ Carol Meyers. 'Was Ancient Israel a Patriarchal Society?' Journal of Biblical Literature 133, no. 1:8.

${ }^{4}$ Lee A. Johnson, 'Social Stratification,' Biblical Theology Bulletin Vol. 43, No. 3, p. 155.
} 
decision and relation regarding men or male mentality. ${ }^{5}$ Colin Farrelly adds, 'Patriarchy is the 'manifestation of institutionalization of male dominance over women and children in the family and the extension of male dominance over women in society in general. ${ }^{6}$

\section{Reexamining Assumptions}

It is a common, long-held assumption is that the patriarchal governing model was instituted by God for all social communities based in the Old Testament, and that it represents God's intended paradigm for human society and authority. 'Since the late nineteenth century, if not before, the term "patriarchy" has been invoked by those seeking to understand the cultural context of biblical texts."7

Nevertheless, the emergence of the Adam and Eve narrative as a pivotal way of understanding God's intention for social community is of surprisingly late origin. 'So wellknown is the Eden narrative of Genesis that it is somewhat surprising to find that the story of Eden is not a prominent theme elsewhere in the Hebrew Bible. Neither are the actions of Eve and Adam ever mentioned as examples of disobedience and punishment, although the long story of Israel's recurrent rejection of God's word and will provides ample opportunity for citing the Eden case. ${ }^{98}$ When the story finally emerges in religious literature and theological discussion in the Hellenistic period, it has been greatly reshaped. 'By then, well after the original shaping of the Eden story, Eve's role is recast by the beliefs and the needs of the nascent Jewish and Christian communities in the Hellenistic-Roman world. So compelling are the views of Eve portrayed in the New Testament, in rabbinic lore, and in the Aprocyphal and Pseudepigraphical

\footnotetext{
${ }^{5}$ Necla Mora, 'Reproduction of Patriarchal Hegemony in Media Texts,' Electronic Journal of Social Sciences, Winter, 2014, Vol. 13, Issue 48, p. 131.

${ }^{6}$ Colin Farelly, 'Patriarchy and Historical Materialism,' Hypatia, vol. 26, no. 1 (Winter 2011), p. 2.

${ }^{7}$ Meyers, p. 8.

${ }^{8}$ Carol L. Meyers, Rediscovering Eve: Ancient Israelite Women in Context, (Oxford University Press, 2013), Kindle edition, location 1.
} 
books that it is difficult to examine the Eve story without being influenced by the dominant Jewish and Christian interpretations of that story. ${ }^{9}$

Beyond Adam and Eve, the bedrock of patriachalism has been formed by using the narrative of Abraham and Sarah. Biblical justification for the patriarchal organizing of our own families, churches, and communities has been espoused as having been modeled after this ancient couple. In fact, Abraham generally has been understood and taught as the first of Israel's patriarchs. A commensurate appellative of matriarch has not been assigned to Sarah. ${ }^{10}$

\subsection{Two Ancient Marriage Systems}

When investigating the tribal family system of this couple, one is struck at the glaring structural and cultural differences found in this historical context from our own. 'To understand the living community of ancient Israel means examining it in the context of its own multidimensional environment, including its social and political prehistory, its ecological environment, and its agrarian-pastoral economic base. Using a variety of resources, scholars have made significant strides in reconstructing the social history of ancient Israel. ${ }^{11}$

It is impossible to understand the story of Abraham and Sarah if one does not approach the story with the realization that two very different systems of marriage were coexisting and competing in early Canaan, and both systems were completely unlike our own present-day nuptial arrangements. An entire theological discussion is constructed upon these two different systems in the book of Galatians:

Tell me, you who want to be under law, do you not listen to the law? For it is written that Abraham had two sons, one by the bondwoman and one by the free woman. But the son

\footnotetext{
${ }^{9}$ Ibid., $1-2$.

${ }^{10}$ Biblically speaking, the Bible makes this inclusion of Sarah's role quite explicitly. See for instance: 'Look to Abraham your father and to Sarah who gave birth to you in pain,' (Isa. 51.2, NAS).

${ }^{11}$ Meyers, Rediscovering Eve, location 307.
} 
by the bondwoman was born according to the flesh and the son by the free woman through the promise. (Gal. 4.21-23, NAS).

Here, Paul draws upon the position of free wife and that of slave wife in order to create an analogous point about law and grace. He assumes that readers will be acquainted with these two systems.

Hand-in-hand with patriarchal structure was patrilineality, that is the ordering of families according to the father's kinship, tribe, and name. Interestingly, in this ancient system that we have been scripted to see as patrilineal, one glaring contradiction arises. Jews must trace their 'Jewishness' through the women, which is to say, one's Jewish descent is based upon the mother's family and not the father's. An individual is considered Jewish only if his or her mother is Jewish, irrespective of the father's national descent. In Western gentile families, we have grown so accustomed to organizing our families through our fathers and tracing our names patrilineally that we can fail to recognize that any other organizing possibilities exist or ever existed.

Biblical scholars are helped by anthropologists and sociologists who explore such tribal arrangements: 'Research data on tribal groups, with their clan and family subdivisions and their characteristic uses of resources and establishment of leadership, help biblical scholars understand the dynamics of Israelite tribal beginnings.' 12 'Scholarship has a long history of engagement with the social sciences, going back to the work of Scotsman William Robertson Smith of the late nineteenth century,' said Meyers. Smith, a Cambridge ${ }^{13}$ pioneer in the study of sociology of religion, affirms the existence of these two marriage systems in ancient Canaan. 'Smith drew on his extensive research on Middle Eastern tribal groups to theorize about various customs and

\footnotetext{
${ }^{12}$ Ibid., location 332.

${ }^{13}$ W. Robertson Smith, Kinship and Marriage in Early Arabia, (Toronto: Beacon Press; 1903), reprint n.d.
} 
social structures of the Israelites. His proposals have since been modified or discarded, but his ideas about the relationship of the realities of the material world to a people's beliefs and practices have had enduring significance. ${ }^{14}$

Early anthropologist John Ferguson McLennan ${ }^{15}$ created volumes on his studies of primitive cultures and early marriage. He said, 'Going back beyond the time of the Patriarchs, we find a piece of evidence which seems absolutely contradictory of the whole Patriarchal Theory. The first reference to marriage in the Scriptures (see Genesis 2.24) mentions father and mother in a breath, and involves that their son left them when he married. 'Therefore shall a man leave his father and mother and shall cleave to his wife.' The words, ascribed to Adam, must be taken as embodying a very early custom. Now what do they mean? Can leaving father and mother (not the father only, observe) mean less than leaving the household, leaving the family, of one's birth?'16

This early kinship arrangement is found throughout the oldest chapters of Scripture. When Abraham seeks a wife for Isaac, his servant believes the condition will be that Isaac will come and settle with her people.

'You shall not take a wife for my son from the daughters of the Canaanites, among whom I live, but you shall go to my country and to my relatives, and take a wife for my son Isaac.'

And the servant said to him, 'Suppose the woman will not be willing to follow me to this land; should I take your son back to the land from where you came?' (Gen. 24.3-5, NAS).

\footnotetext{
${ }^{14}$ Carol L. Meyers, Rediscovering Eve: Ancient Israelite Women in Context, (Oxford University Press, 2013), Kindle edition, location 287.

${ }^{15}$ McLennan, John Ferguson born Oct. 14, 1827, Inverness, Inverness-shire, Scotland, died June 16, 1881; Scottish lawyer and ethnologist whose ideas on cultural evolution, kinship, and the origins of religion stimulated anthropological research. McLennan was admitted to the bar in 1857, and he became a parliamentary draftsman for Scotland in 1871.

${ }^{16}$ John Ferguson McLennan, ed. Donald McLennan, The Patriarchal Theory, (London: Macmillan and Co.; 1885): p. 41 .
} 
A second illustration of this early ancient marriage type is found in the story of Jacob. McLennan says both these marriages represent examples of this ancient marriage arrangement. Laban had the law on his side in saying that Jacob had no right to carry off his wives and their children.

And Laban caught up with Jacob. Now Jacob had pitched his tent in the hill country, and Laban with his kinsmen camped in the hill country of Gilean. Then Laban said to Jacob, 'What have you done by deceiving me and carrying away my daughters like captives of the sword?' (Gen. 31.25-26 NAS).

'....and did not allow me to kiss my sons and daughters? You have done foolishly. It is in my power to do you harm, but the God of your father spoke to me last night...' (Gen. 31.28-29 NAS).

Then Laban answered and said to Jacob, 'The daughters are my daughters, and the children are my children, and the flocks are my flocks, and all that you see is mine' (Gen. 31.43 NAS).

'Joseph's children by his Egyptian wife were Israelites by adoption,' according to McLennan, citing the mysterious words and ceremony of Jacob at his death: 'And now your two sons, who were born to you in the land of Egypt before I came to you in Egypt, are mine; Ephraim and Manasseh shall be mine, as Reuben and Simeon are' (Gen. 48.5). ${ }^{17}$

Samson's story provides one of the best illustrations of the ancient kinship laws. In Judges 15 we learn that Samson went back and forth to visit his wife. McLennan says, 'And so in Judges 15, Samson's Philistine wife remains with her people and he visits her there. ${ }^{18}$

But after a while, in the time of wheat harvest, it came about that Samson visited his wife with a young goat, and said, 'I will go in to my wife in her room. But her father did not let him enter' (Judg. 15.1).

John Punnett Peters,${ }^{19}$ wrote of this ancient time when early tribes were arranged under the mothers. He said, 'It would seem as though we had a survival of the old matriarchate, that

\footnotetext{
${ }^{17}$ John Ferguson McLennan, ed. Donald McLennan, The Patriarchal Theory, (London: Macmillan and Co.; 1885), 43-44.

${ }^{18}$ Katharine C. Bushnell; God's Word to Women, (North Collins, NY: Ray B. Munson): 57-58; W. Robertson Smith, Kinship and Marriage in Early Arabia, (Toronto: Beacon Press; 1903), p. 207.

${ }^{19}$ American archaeologist, first scientific director of the Babylonian Exploration Fund and professor of Semitics at the University of Pennsylvania. He is credited with overseeing the first archaeological investigations that discovered 60,000 Sumerian cuneiform tablets.
} 
relation of marriage of which we have an example in the Samson story, where the woman remains with her tribe, or clan, or family, and is visited by the man. The offspring in such a case belongs to the woman's family, not the man's. ${ }^{20}$

Flinders Petrie said, 'We have become so accustomed to the idea that women were always dependent in the East—as they are now under Mohammedanism— that we need to open our eyes to a very different system which is shown us in the early history of the patriarchal age. The early ideal in the East was separate worlds of men and women, while women retained their own rights... ${ }^{21}$ Johann Jakob Bachofen wrote extensively about this ancient period that preceded classical times, calling it an era of 'mother right.' Many of these scholars' thinking was influenced by Darwinism, supposing that society evolved from this matriarchal arrangement, which they viewed as more, into what they considered a more evolved, patriarchal one.

\subsection{Sarah and Abraham's Conflict in Light of These Customs}

From this perspective, the argument Sarah and Abraham had over the slave child Ishmael takes on new meaning. The customs of the time allowed Sarah to have a baby through her slave girl, Hagar,- - an ancient version of surrogate motherhood. Abraham and Sarah argued over the results, and much of the trouble appears to have arisen over the divergent expectations resulting from these two marriage systems. Under one system, a slave born to a free man would be a free person. So, the baby, Ismael, born to Abraham and Hagar, would be free. The kinship rights would be determined by the father's freedom, with Sarah being set aside. Interestingly, however, had this system been used to resolve the conflict, the final outcome would have rendered the rights of the first born not to Isaac, but to Esau.

\footnotetext{
${ }^{20}$ J.P. Peters, Early Hebrew Story, (New York: G. P. Putnam; London: Williams and Norgate; 1904), p. 223; in Bushnell, p. 57.

${ }^{21}$ Bushnell, p. 58.
} 
However, under the system where in Sarah was a free tribal mother, a slave born by her slave woman would remain a slave, the kinship status being determined by the slave mother, who was the property of Sarah. Additionally, under the first system, all property would belong to Abraham. But under the second system, the slave Hagar would be considered Sarah's property, not Abraham's. A child born to Sarah's slave also would be Sarah's slave child by ownership. She might then take this same slave and make him an heir. This same method of naming an heir was offered to God by Abraham regarding his faithful slave Eliezer of Damascus (see Gen. 15.2). God refused Eliezer, preferring a biologically born heir. It was this tradition of raising up a slave to the position of an heir that Sarah offered to Abraham to meet the need. Galatians calls this the 'free wife' system of marriage.

Under the slave wife system, Abraham could raise Hagar, 'his slave,' up to the status of wife. Abraham, who had historically shown himself as less than committed to his wife's rights and overall welfare, again betrays her. He was willing to set her aside, which was far from the initial terms of the deal they had struck. Under one system, Ishmael would have been Abraham's own child, not Sarah's slave child. Ishmael would not be a slave, but free, based upon the kinship of the father. This is what was happening to Sarah, which was why she told Abraham, 'May the wrong done me be upon you' (Gen. 16.5). The child was not given to the free wife Sarah as her slave child; rather, the slave woman was being lifted up above Sarah as Abraham's slave wife.

When free wife, Sarah, says, 'May the Lord judge between me and you,' (Gen. 16.5), she calls for God's decision regarding property rights, marriage systems and the rights of inheritance. Abraham answers, 'Behold your maid is in your power; do to her what is good in your sight' (emphasis is mine). Abraham has recanted and accepted the original terms of the agreement and acknowledges Sarah's ownership of her slave and the slave child. 


\subsection{Matrilineality and Tribal Identity}

The legitimacy of the nation of Israel was at stake, which we must surmise is the reason that Jews continue to this day to find their racial identity through their mothers. The children of Ishmael, Abraham's first son according to patrilineality, were not named as Abraham's heirs. It is just on this point that the Arab nations claim to be Abraham's true heirs, and based upon patrilineality, as opposed to matrilineality, their claim would be legitimate. Matrilineality invalidates this claim. Abraham had other children following the death of Sarah, but none of these are considered heirs of God's promise, only the one child of Sarah by virtue of matrilineality.

\subsection{Sweeping Implications}

Recall that Hagar's son, Ishmael, became the mother of all of the Arab tribes other than Israel, who was the son of Sarah's offspring, Isaac. What must be fully recognized and appreciated is that the claim of Arab nations against Israel—and, secondarily, against Christians, by virtue of their rootedness in Isaac's kinship and promise — would be valid based upon patrilineality. It seems interesting then that both Jews and Christians came to embrace the patriarchal lineality that Arab nations cite when asserting their claim against them. Only according to matrilineality is the claim of being God's chosen, which was promised to Abraham, realized in the Jews and Christians. In rejecting Sarah's claim, both Jews and Christians fall into the trap of rejecting their own claim of chosenness and inadvertently affirm the basis for the Arab claim that neither Jews nor Christians have the right to exist as God's chosen people. This may seem speculative and remote to us, but to Arab tribes, it is far from being the case. ${ }^{22}$

\footnotetext{
${ }^{22}$ Author's note: as a Pentecostal, let me be bold enough to offer a prophetic addendum to this point. In Genesis 4, God integrated the kinship of women with his promises when he said, 'The seed of the woman shall crush the head of the serpent.' In the epic battle for patriarchy, we must note that the enmity that God placed between the serpent and the woman has continued to rage over the centuries and continues to do so all the more.
} 


\subsection{Continuing Matrilineal Generations}

A few generations later, we see Rachel and Leah give their slaves to Jacob to produce more children. These children were then called the children of Rachel and Leah, not of Jacob. The property rights held as did the matrilineality. Rachel and Leah also lived in their own tents. With reference to the marriage system narrative and Sarah's call for divine adjudication, God had judged in Sarah's favor.

\subsection{Bride Abductions and Tribalism}

Abductions of women were so common during the couple's era that Abraham was certain that he and Sarah would experience them in their travels when they both answered God's call to leave their homeland (see Genesis 20). As feared, Sarah was abducted twice during their travels. Rebekah, her daughter-in-law, faced similar danger (see Genesis 26.7-8). Even Dinah, Sarah's great-granddaughter, was abducted by another tribe, raped, and forced into an unwanted union. Scholars agree that a time of widespread abductions of women occurred over a significant period to time, which accounts for the changing of marriage systems (see Genesis 30). This time of widespread bridal abductions doubtless played a large role in shifting Semitic tribal customs regarding marriage as we shall see.

Social anthropologist Edward Westermark said, 'The practice of capturing wives prevails in various parts of the world, and traces of it are met within the marriage ceremonies of several peoples, indicating that it occurred much more frequently in past ages. ${ }^{23}$ That bride abductions existed in the ancient past should not surprise us, as they have tended to continue in certain more primitive demographic groups. 'Bride abduction is a marriage practice that has been found in

\footnotetext{
${ }^{23}$ Edward Alexander Westermarck, The History of Human Marriage, (Elibron Classics: Adamant Media Corporation, 2005; a replica edition of Macmillan and Co. Ltd., London: 1903) p. 383.
} 
settings across Europe, Asia, Africa, Australia, and the Americas. In a cross-cultural analysis, Barbara Ayres distinguishes four different marriage practices that involve the abduction of the bride. ${ }^{24}$ At the end of the book of Judges, we see the widespread degeneration and chaos as bride abductions found their way into the tribes of Israel. The sad chapter ends with the words: '...everyone did what was right in his own eyes' (Judg. 21.25).

Such an anthropological look into the historical cultural practices of ancient Israel provides important insight into the actual lives and practices of these ancient peoples. 'Crosscultural studies of forces leading to state formation and the growth of bureaucracies contribute to a better appreciation of the Israelite shift from tribal organization or chieftaincy to kingship. ${ }^{25}$

\section{Tribal Mothers of the Bible}

To a great extent, the commonly held theological construct of our present-day system of male hierarchy is rooted in a patriarchal understanding of Abraham, Isaac, and Jacob's stories as the patriarchs of God's people. Yet, the biblical account gives as much emphasis to matriarchal position as it does to the role and position of the patriarchs. Tribal Mother Sarah's name is an interesting one. Of it, Petrie writes, 'The first woman that appears as a personality in the Old Testament is Sarah, the 'chieftainess,' as her name implies. Sar is the regular old term for a chief, still kept up in the East. Sarah had her independent residence a Mamre, and lived there, while Abraham lived at Beersheba; and it is said that he came to mourn for her and to bury her. Her position, therefore, during her wanderings and in later life was not by any means that of secluded dependence, but rather of an independent head of the tribe, or "tribal mother.",26

\footnotetext{
${ }^{24}$ Cynthia Werner, 'Bride abductions in post-Soviet Central Asia: marking a shift towards patriarchy through local discourses of shame and tradition,' Journal of the Royal Anthropological Institute, 15; 314-331, 2009, p. 2.

${ }^{25}$ Meyers, Rediscovering Eve, location 339.

${ }^{26}$ Katharine C Bushnell, God's Word to Women, (North Collins, NY: Ray B. Munson): p. 59.
} 


\subsection{Mother Kinship}

We have grown accustomed to the concept of patriarchy being employed in the establishment of family genesis and names. The Bible's genealogies are filled with the names of fathers who begat sons, with few accounts of matriarchal lineage. Such a perspective seems to support today's concept of patriarchal government.

Speaking of Genesis 2.24, Bushnell writes, 'And we might ask, what does that primitive form of language mean, — 'cleave to his wife; and they shall become one flesh,' but that he shall become of the same kin as his wife?'27 Smith says, 'Mother kinship is the type of kinship, common motherhood the type of kindred unity, which dominates all Semitic speech. ${ }^{28}$ Jackie Smith Arnold describes a prehistoric time when families were organized under females. Children were tremendously important to the small bands of struggling humanity, so birth was more significant than conception. Out of necessity, matrilineal kinship was the only form observed. 'If an imaginary female named Ana had scratched her family tree on the cave wall, she would have provided an idea of how cognate (related to the mother's side) kinship was observed. ${ }^{29}$ Interestingly, this secular text says that 'a new theory concludes that every person living today is descended from one African female who walked the earth 140,000 to 280,000 years ago. ${ }^{30}$ Such a theory echoes Adam's ancient exclamation: 'Now the man called his wife's name Eve, because she was the mother of all living' (Gen. 3.20). If, in fact, families in antiquity were arranged under women and not men, then questions regarding the naming of children might arise.

\subsection{Feminine Eponyms}

\footnotetext{
${ }^{27}$ Ibid., pp. 57-58.

${ }^{28}$ Ibid.

${ }^{29}$ Jackie Smith Arnold, Kinship, It's All Relative, (Baltimore: Genealogical Publishing Co., 1990) p. 2.

${ }^{30}$ Ibid., p. 3.
} 
As a Semitic language specialist, Smith spent a lifetime researching the early Middle East, its languages, and customs. He discovered that many ancient tribal names were derived from feminine eponyms. An eponym, is 'a person, real or imaginary, from whom something, as a tribe, nation, or place, takes or is said to take its name. ${ }^{31}$ Entire tribes and offspring were commonly named after mothers instead of fathers as we name our families today. In other words, if this system were in place today, offspring would take their mother's last names. Can even this important aspect of matriarchal leadership be found with respect to our first family of faith? Smith says, '...Female eponyms are frequently referred to in a very remote antiquity, just as in Hebrew Leah is more ancient than Levi and Sarah than Israel. ${ }^{32}$ Julius Wellhausen's reconstruction of the literary development of the Hebrew Bible remains a prominent, albeit controversial, part of biblical studies. ${ }^{33}$ He writes: 'For as Levi is the patronymic corresponding to Leah, ${ }^{34}$ I do not remember to have seen it pointed out that Sarah corresponds just as closely with Israel. The masculine name corresponding to Sarah is Seraiah, which stands to Israel as Hezekiah does to Ezekiel. ${ }^{35}$ Smith says that the name of Levi and the Levite tribe came from its tribal mother, or matriarch, Leah. The name of Israel and his tribal name were derived from Sarah, whose name was a more ancient feminine equivalent.

\subsection{Old Testament Land Apportionments}

If it is then true that the tribes were named matrilineally and not patrilineally, what, then, are we to make of the Bible's patrilineal genealogies, which have been used to advantage in supporting the sense of a biblical, 'God-ordained' patriarchal script? Meyers says, 'Biblical genealogies,

\footnotetext{
${ }^{31}$ Random House Webster's Unabridged Dictionary, (New York: Random House, 1997), p. 655.

${ }^{32}$ W. Robertson Smith, Kinship and Marriage in Early Arabia, (Toronto: Beacon Press, 1903), p. 34.

${ }^{33}$ Meyers, location 294.

${ }^{34}$ Julius Wellhausen, Prolegomena to the History of Israel; (Whitefish, Montana: Kessinger Publishing, n.d.), p. 141.

${ }^{35}$ Smith, p. 34.
} 
which rarely include female names, reflect this concern for male lineages, or patrilineages. These genealogies were not entirely records of social reality. To a certain extent they were literary constructs meant to establish 'blood' connections among neighboring groups in order to secure stable intergroup relationships. Biblical genealogies thus connect all the disparate tribal groups and subgroups into a symbolic family tree. Omitting women accommodated the patrilineal principle and also gave the formation of genealogies the flexibility they needed to accommodate out-of-group marriages and thus new connections. ${ }^{, 36}$

In addition to genealogies, the land apportionments of the twelve male brother tribes of Israel also have been used to support the enduring patriarchal script.
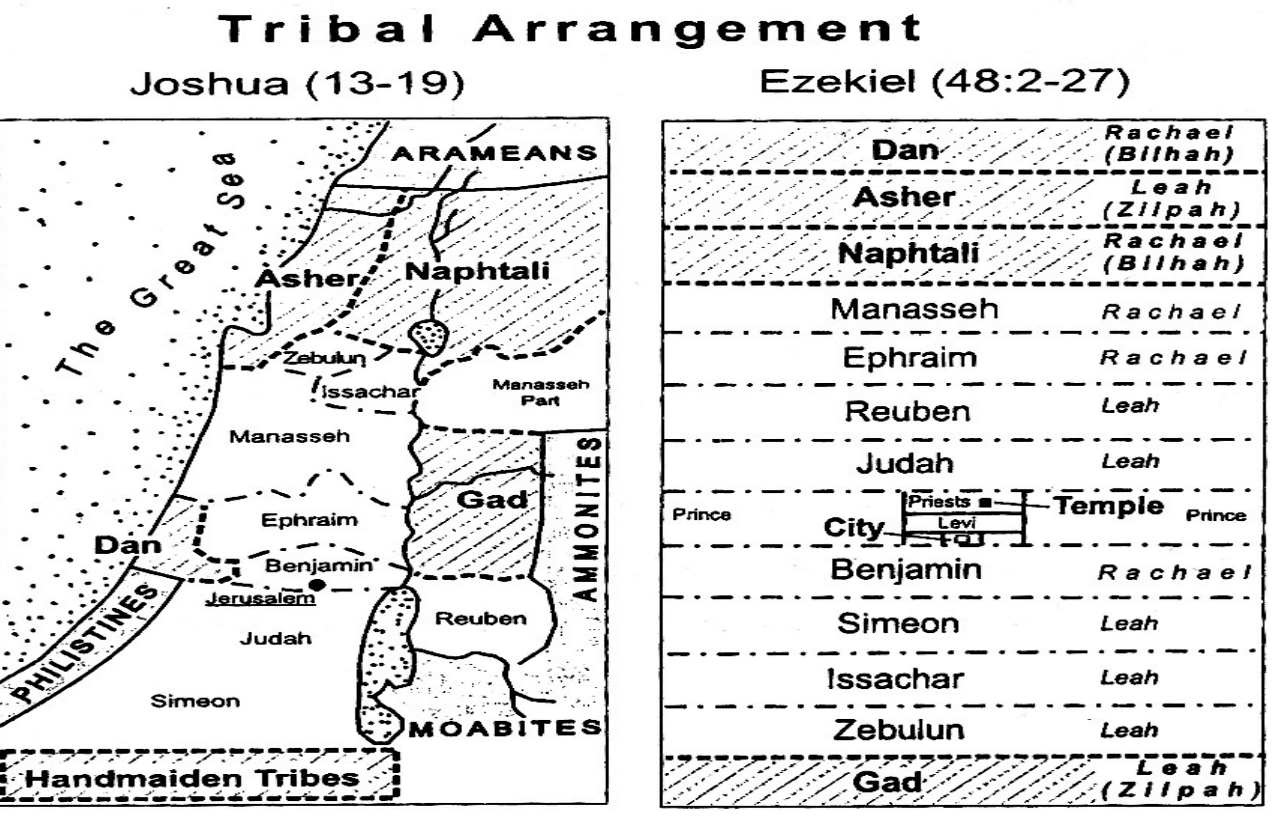

Tribal Arrangement Figure 1.

With respect to the land portion apportionment of the twelve brother tribes, it is interesting to note that, arguably, the tribes were arranged with the best land portions gifted to the sons of the free wives. The allotments placed farther from the temple, considered to be inferior portions,

\footnotetext{
${ }^{36}$ Meyers, Rediscovering Eve, location 485.

${ }^{37}$ Harold Brodsky, 'The Utopian Map in Ezekiel”' (48.1-35), Jewish Bible Quarterly, 2006, p. 20; jbq.jewishbible.org.
} 
were officially called the 'handmaiden tribes.' 'Ezekiel, like Joshua, located the 'handmaiden' tribes in peripheral frontier areas. ${ }^{38}$ In other words, the twelve 'son' tribes were something of subsets of the mother's portions, under whose names they were primarily aligned, according to the tribal rights discussed earlier. The apportionment of tribal properties was in line with female, not male, patrimony. Once again, had the tribal arrangements been designated according to pure patrimony, the apportionments would not have been arranged based upon the perceived positional value of the mothers. Here, again, one sees that the traditional notions of Israel as a pure patriarchy are more myth than fact, with the early females presiding as matriarchs who clearly were personages in their own right.

\section{The Ancient Cultural Integration of Women}

It seems impossible to ascribe to the notion that God reduced women to a second-class position based upon the old patriarchal model. Traditions and customs beyond these ancient discussions of marriage and property rights tend to support a wider role for women in ancient Israeli culture. 'We see that women were not excluded from all professional positions serving the wider community. Their positions were in fact numerous and varied; about twenty different ones are mentioned in the Hebrew Bible. ${ }^{39}$ These include: judges, sages, royal women, poets, prophets, singers, dances, instrumentalist, and mourners. 'Most of these professional women possessed considerable expertise and made significant contributions to their communities, and many provided authoritative services. They were hardly all dominated or controlled by male hierarchies. ${ }^{40}$ A woman's household authority was upheld in the laws that punished children for disrespecting both fathers and mothers. In addition, the managerial power of women over their

\footnotetext{
${ }^{38}$ Ibid., p. 22.

${ }^{39}$ Carol L. Meyers, 'Was Ancient Israel a Patriarchal Society?' Journal of Biblical Literature, 133, no. 1 (2014), p. 23.

${ }^{40}$ Ibid. p. 23.
} 
households is depicted in the several narratives, including the Shunammite who acts quite autonomously in inviting Elisha into the household, reconfiguring space, traveling, and negotiating. Abigail, who met David in his travels, is presented in similar fashion, as a female manager who holds enormous autonomous power over her household. The Proverbs 31 woman is lauded as one who considers and field and buys it, who manages her household well, and who successfully increases income and who is known in the gates where ruling takes place. 'The term 'patriarchy' as a designation of general male domination of women, would thus be inappropriate and inaccurate. ${ }^{41}$

6 Conclusion

The details of matriarchal leadership are not offered here in an attempt to replace the current notions of patriarchy with matriarchal ones. Rather, they are offered to demonstrate that a patriarchal governmental template based upon Old Testament narrative features lacks veracity. After reexamining numerous matriarchal elements also found in the biblical narrative, one must conclude that these ancient systems of marriage and government were entirely unlike our own, and that any attempt to draw an accurate model and apply it to our own culture seems unwise.

From the Old Testament narrative we witness a God who affirmed, valued, and called to service both men and women into many roles and positions, including those of leadership. That there are elements of patriarchal leadership in Old Testament life is without dispute. However, this paper has attempted to demonstrate that in addition to such characteristics of ancient Semitic life in God were also important matriarchal features as well, which lend support to God's creation admonition to both genders together to 'let them rule' (see Gen. 1.26). 7 Bibliography

\footnotetext{
${ }^{41}$ Ibid. pp. 22-23.
} 
Arnold, Jackie Smith, Kinship, It's All Relative, (Baltimore: Genealogical Publishing Co., 1990).

Bachofen, J.J., trans., Manheim, Ralph, Myth, Religion, and Mother Right, (New Jersey: Princeton University Press, 1967).

Brodsky Harold, 'The Utopian Map in Ezekiel, (48.1-35),' Jewish Bible Quarterly, 2006jbq.jewishbible.org.

Brueggemann, Walter, 'Counterscript: Living with the Elusive God,' Christian Century Nov. 29, 2005.

Brueggemann, Walter. Old Testament Theology: An Introduction (Nashville, TN.: Abingdon, 2008).

Brueggemann, Walter, The Prophetic Imagination, Second Edition. (Minneapolis: Fortress Press, 2001).

Bushnell, Katharine C., God's Word to Women, Woman's Place in the Divine Economy, (North Collins, NY: Ray Munson, 1923).

Colwell, Ernest C., New or Old? The Christian Struggle with Change and Tradition, (Philadelphia: The Westminster Press, 1970).

Dickerson, Victoria. 2013. 'Patriarchy, Power, and Privilege: A Narrative/Poststructural View of Work with Couples.' Family Process 52, no. 1:102-114.

Farrelly, Colin. 2011. 'Patriarchy and Historical Materialism.' Hypatia 26, no. 1:1-21.

Gibson, John Monroe, The Ages Before Moses, (New York: Anson D. F. Randolph, 1879).

Johnson, Elizabeth A., She Who Is: The Mystery of God in Feminist Theological Discourse (New York: Crossroad, 2005).

Johnson, Lee A. 2013. 'Social Stratification.' Biblical Theology Bulletin 43, no. 3:155-168.

Kelly-Zukowski, Mara. 2005. 'The Catholic Church's Restrictions on Female Participation and Some Biblical Responses.' Gender Issues 22, no. 4:43-55.

Lenski, Gerhard E., Power and Privilege: A Theory of Social Stratification, (Chapel Hill: The University of North Carolina Press, 1984).

Lietzmann, Hans, The Era of the Church Fathers, A History of the Early Church, vol. IV, trans., Woolf, Bertram Lee, (New York: Charles Scribner's Sons, 1952).

Means, Russell. 2011. 'Patriarchy: The Ultimate Conspiracy; Matriarchy: The Ultimate Solution: History-or "His-story".' Griffith Law Review 20, no. 3:515-525.

Meyers, Carol L., Rediscovering Eve: Ancient Israelite Women in Context, (Oxford University Press, 2013), Kindle edition.

Meyers, Carol L. 2014. 'Was Ancient Israel a Patriarchal Society?.' Journal of Biblical Literature 133, no. 1: 8-27.

McLennan, Donald, ed., The Patriarchal Theory, Based Upon the Papers of the Late John Ferguson McLennan, (London: Macmillan and Co.; 1885). 
Ora, Necla. 2014. 'Reproduction of Patriarchal Hegemony in Media Texts,' Electronic Journal of Social Sciences 13, No. 48: 131-147.

Peters, John P., Early Hebrew Story, (Williams and Norgate, 1904).

Reid, Barbara E. 2008. 'What's Biblical about...the Priesthood?' Bible Today 46, no. 5: 331-33.

Smith, W. Robertson, Kinship and Marriage in Early Arabia, (Boston: Beacon Press, 1903).

Wellhausen, Julius, Prolegomena to the History of Israel; (Whitefish, Montana: Kessinger Publishing, n.d.).

Werner, Cynthia. 2009. 'Bride abduction in Post-Soviet Central Asia: marking a shift towards patriarchy through local discourses of shame and tradition,' Journal of the Royal Anthropological Institute 15, no. 2:314-331.

Westermarck, Edward Alexander, The History of Human Marriage, (Elibron Classics series, Adamant Media Corporation, 2005; London: Macmillan and Co., Ltd., 1903). 